\title{
PENGARUH KOMPETENSI SUMBER DAYA MANUSIA, TEKANAN EKSTERNAL, KOMITMEN ORGANISASI, DAN SISTEM PENGENDALIAN INTERN TERHADAP PENERAPAN TRANSPARANSI PELAPORAN KEUANGAN PEMERINTAH DAERAH (STUDI EMPIRIS PADA ORGANISASI PERANGKAT DAERAH KABUPATEN ROKAN HILIR)
}

\author{
Siti Puji Rahayu ${ }^{1}$, Ruhul Fitrios ${ }^{2}$, Sem Paulus ${ }^{3}$ \\ Prodi Akuntansi Fakultas Ekonomi dan Bisnis Universitas Riau \\ ${ }^{1}$ sitipujirahayu03@gmail.com. ${ }^{2}$ ruhul.fitrios@lecturer.unri.ac.id ${ }^{3}$ semsilalahi@gmail.com
}

\begin{abstract}
The main objective of this study is to examine the competence of human resources, external pressures, organizational commitment, and internal control systems in the implementation of financial verification in OPD Rokan Hilir using data analysis methods using Structural Equation Modelling-Partial Least Square (SEM-PLS) by using Warp-PLS version 5.0. The populationin this study are all Regional Apparaturs Organization(OPD) kabupaten Rokan Hilir. Sample selection used the slovin method as a measuring tool for calculating sample sizes. Respondent in this study are head of offices, employees in the section/unit that manages finance using the application of financial reporting transparency in 40 OPDs in the goverment kabupaten rokan hilir. So the total number of questionnaires tobe distributed is 120. The results of this study indicate that Human Resource Competency, External Pressure, Organizational Commitment, and Internal Control Systems have a positive effect on the Implementation of Transparency in Regional Government Financial Reporting
\end{abstract}

Keywords: Implementation of Financial Report Transparency, Human Resources Competence, External Pressure, Organizational Commitment, Internal Control Systems

\section{PENDAHULUAN}

Pesatnya perkembangan otonomi daerah di Indonesia saat ini mencerminkan adanya respon rakyat yang sangat tinggi akan permintaan tata kelola pemerintahan yang baik (good goverment governance). Aspek keuangan negara menduduki posisi strategis dalam proses pembangunan bangsa, baik dari segi sifat, jumlah, maupun pengaruhnya terhadap kemajuan, ketahanan, dan kestabilan perekonomian bangsa sehingga salah satu upaya untuk mewujudkan tata kelola pemerintah yang baik tersebut adalah dengan cara meningkatkan transparansi dan akuntabilitas pengelolaan dan pelaporan keuangan daerah. Pengelolaan keuangan daerah mengatur semua aspek teknis mencakup bidang peraturan, kelembagaan, sistem informasi keuangan daerah, dan peningkatan kualitas sumber daya.

Mardiasmo (2018:274) menyatakan bahwa transparansi dan akuntabilitas adalah salah satu kunci keberhasilan desentralisasi fiskal dan otonomi daerah. Kedua hal ini sangat penting untuk menjaga organisasi yang diberikan kewenangan untuk mengelola sumber daya publik dalam rangka memberikan layanan terbaik kepada masyarakat. Selain itu pengelolaan sumber daya pembangunan oleh pemerintah daerah menjadi lebih fleksibel, transparansi merupakan kunci untuk mengawal mekanisme akuntabilitas yang
ada.Tantangan untuk dapat merealisasikan tujuan di atas tidaklah mudah. Ini bisa disebabkan karena perilaku usaha dan pelayanan publik yang dilakukan pemerintah selama ini telah tercemar dengan berbagai bentuk tindakan, kegiatan, dan modus yang tidak sehat sehingga adanya praktek korupsi, kolusi, dan nepotisme (KKN).

Dalam Peraturan Menteri Dalam Negeri No 59 Tahun 2007 dalam pasal 116 ayat (4a) yang berbunyi "untuk memenuhi asas transparansi, kepala daerah wajib menginformasikan substansi APBD kepada masyarakat yang telah di undangkan dalam lembaran daerah, jadi pemerintah daerah berkewajiban untuk memberikan informasi keuangan dan informasi lainnya yang akan di gunakan dalam pengambilan keputusan. Jika tidak dilaksanakannya transparansi akan menimbulkan dampak negatif yang sangat luas bagi masyarakat seperti, penyalahgunaan wewenang dan kekuasaan, ketidakadilan bagi masyarakat, serta penyuburan praktik-praktik korupsi.

Menurut PP 71 Standar Akuntansi Pemerintah tahun 2010 menyatakan bahwa transparansi memberikan informasi keuangan yang terbuka dan jujur kepada masyarakat memiliki hak untuk mengetahui secara terbuka dan menyeluruh atas pertanggungjawaban pemerintah dalam pengelolaan 
sumber daya yang dipercayakan kepadanya dan ketaatannya pada peraturan perundang-undangan. Transparansi pelaporan keuangan dapat diwujudkan melalui publikasi media massa atau mengundang perwakilan masyarakat. Oleh karena itu, pemerintah daerah dapat memanfaatkan keberadaan website resmi pemerintah daerahnya masing-masing untuk mewujudkan transparansi penglolaan keuangan daerah tersebut (Abdul Halim, 2016).

Berdasarkan hasil penelusuran terhadap 12 website pemerintah kabupaten/kota se Provinsi Riau menggunakan penilaian sesuai instruksi Mendagri Nomor 188.52/1797/SJ Tahun 2012 tentang Transparansi pengelolaan Anggaran Daerah. Didapatkan bahwa seluruh pemerintah daerah di provinsi Riau telah memiliki website respi dan dapat diakses, terdapat 4 daerah yang memiliki konten transparansi pengelolaan anggaran daerah yaitu(Kabupaten Kampar, Kabupaten Kuantan Singingi, Kabupaten Rokan Hulu, dan Kota Dumai) dan (Kota Pekanbaru, Kabupaten Bengkalis, Kabupaten Indragiri Hulu, Kabupaten Pelalawan, dan Kabupaten Rokan Hilir) menampillkan konten transparansi yang berbeda. Dari seluruh dokumen anggaran yang wajib dipublikasikan hanya Kabupaten Indragiri Hulu, Kabupaten Pelalawan dan Kota Dumai yang telah mempublikasikan dokumen anggaran secara utuh dan selebihnya Kota Pekanbaru, Kabupaten bengkalis, Kabupaten Kampar, Kabupaten Rokan Hilir hanya menampilkan beberapa dokumen anggaran(riaupos.com).

Forum Indonesia Transparansi Anggaran (FITRA) riau menilai rendahnya keterbukaan informasi publik dan korupsi di provinsi riau, baik provinsi maupun kabupaten/kota belum menunjukkan adanya perbaikan. Koordinator FITRA Riau Triono Hadi mengungkapkan bahwa masih tingginya praktik korupsi diriau dilihat dari hasil survey KPK, dimana indeks integritas korupsi yang dinilai tahun 2017 lalu menunjukkan riau pada indeks yang rendah. Triono juga mengungkapkan tidak hanya indek integritas yang rendah, persepsi masyarakat terhadap penyelenggaraan pemerintah juga masuk dalam survey indek yang semakin buruk. Kondisi ini semakin diperparah dengan adanya rapor merah dari komisi informasi pusat yang menyatakan bahwa keterbukaan informasi publik diriau tahun 2018 belum dinyatakan sebagai daerah yang masuk dalam kategori informatif. Triono mengatakan transparansi menjadi salah satu indikator upaya pencegahan korupsi yang dilakukan, hal ini terkait dengan bagaimana mendorong partisipasi masyarakat dalam pengawasan pembangunan (Tribunpekanbaru.com).

Fenomena lainnya adalah tentang tuntutan transparansi pengelolaan Dana Desa 2018 dan 2019 yang terjadi di kabupaten mojokerto. Koordinator aksi warga desa cendono yaitu Hadi Purwanto mengatakan bahwa warga hanya ingin transparansi pengelolaan dana desa, Itu hak yang dijamin hukum. Ia juga menjelaskan bahwa warga menemukan beberapa keganjilan dalam penggunaan Dana Desa di Cendoro selama 2 tahun terakhir. Salah satu keganjilan tersebut adalah Pemerintah Desa Cendoro enggan memberikan data proyek-proyek yang menggunakan Dana Desa. Padahal kekuatan APBDes Cendoro 2018 mencapai Rp 1,2 miliar. Sedangkan tahun 2019 Rp 1,7 miliar. Mereka juga telah berulang kali meminta data tersebut. Mulai proyek peningkatan dan pembangunan beberapa jalan di Cendoro, pemeliharaan TK, pendidikan dan pelatihan kades, perangat desa dan BPD, penanaman modal BUMDes, lomba kepemudaan, pembangunan sanitasi permukiman, pelatihan kerja kelompok pemuda, hingga pembangunan tembok penguat tanah jalan usaha tani (detik.com). Beberapa faktor yang mempengaruhi penerapan transparansi pelaporan keuangan yaitu; kompetensi sumberdaya manusia, tekanan eksternal, komitmen organisasi dan sistem pengendalian intern.

Kompetensi merupakan dasar kemampuan seseorang untuk mencapai kinerja tinggi dalan menyelesaikan tugasnya. Sumber daya manusia yang tidak memiliki kompetensi tidak akan dapat menyelesaikan pekerjaannya secara efisien, efektif, dan ekonomis (Mardiasmo, 2004:146) seperti pekerjaan yang dihasilkan tidak akan tepat waktu dan terdapat pemborosan waktu serta tenaga. Dengan adanya kompetensi sumber daya manusia maka waktu pembuatan laporan keuangan akan dapat dihemat. Hal ini karena sumber daya manusia tersebut telah memiliki pengetahuan dan pemahaman mengenai halhal yang harus dikerjakan, sehingga laporan keuangan yang disusun dapat diselesaikan dan disajikan tepat pada waktunya. Semakin cepat laporan keuangan disajikan maka akan semakin baik dalam hal pengambilan keputusan (Ridha dan Basuki, 2012).

Tekanan eksternal merupakan tekanan yang berasal dari luar organisasi yang dapat berpengaruh terhadap organisasi, baik itu berpengaruh terhadap struktur maupun kegiatannya. Adapun faktor eksternal ialah adanya peraturan oleh organisasi lain seperti pemerintah pusat, lembaga pemerintah, maupun lembaga swadaya masyarakat.

Utamaningsih (2014:144) menjelaskan bahwa komitmen organisasi merupakan identifikasi dan keterlibatan seseorang yang relative kuat terhadap organisasinya. Komitmen organisasional adalah keinginan para anggota organisasi untuk tetap mempertahankan keanggotaannya dalam organisasi dan bersedia melakukan usaha yang tinggi bagi pencapaian tujuan organisasi. Komitmen 
organisasional mencakup: kebanggaan anggota, kesetiaan anggota, dan kemauan anggota.

Faktor lainnya yang mempengaruhi penerapan transparansi keuangan adalah sistem pengendalian intern. Menurut I Gusti Agung Rai (2008: 283) Sistem pengendalian intern adalah kebijakan dan prosedur yang dirancang untuk memberikan keyakinan yang memadai bagi manajemen bahwa organisasi mencapai tujuan dan sasarannya.

Berdasarkan uraian pada latar belakang masalah, maka dapat dibuat rumusan masalah yaitu; Apakah kompetensi sumberdaya manusia, tekanan eksternal, komitmen organisasi, dan sistem pengendalian intern berpengaruh terhadap penerapan transparansi pelaporan keuangan pemerintah daerah kabupaten rokan hilir. Penelitian ini bertujuan untuk menguji pengaruh kompetensi sumberdaya manusia, tekanan eksternal, komitmen organisasi, dan sistem pengendalian intern berpengaruh terhadap penerapan transparansi pelaporan keuangan pemerintah daerah.

\section{TINJAUAN PUSTAKA}

\section{Landasan Teori}

Falkman dan Tagesson (2008) dan Pina et al. (2010) menyatakan bahwa teori institusional (institutional theory) dan teori keagenan (agency theory) merupakan dua teori yang bersifat komplementer untuk menjelaskan praktek pelaporan keuangan Pemerintah daerah. Pemikiran yang mendasari teori institusional (institusional theory) adalah didasarkan pada pemikiran bahwa untuk bertahan hidup, organisasi harus menyakinkan kepada publik atau masyarakat bahwa organisasi adalah entitas yang sah (legitimate) serta layak untuk didukung (Meyer dan Rowan, 1977). Scott (2008) menjelaskan bahwa teori institusional digunakan untuk menjelaskan tindakan dan pengambilan keputusan dalam organisasi publik. Teori keagenan menjelaskan bahwa hubungan antara manajer pemda (kepala daerah) dan pemilih (voter) dapat digambarkan sebagai hubungan keagenan, dimana voter adalah prinsipal dan Kepala Daerah adalah agen. Hubungan keagenan ini dapat menimbulkan masalah keagenan sehingga prinsipal mempunyai insentif untuk memonitor perilaku agen (Zimmerman,1977). Pelaporan keuangan (termasuk melalui internet) merupakan sebuah upaya untuk mengurangi asimetri informasi antara prinsipal dan agen. Prinsipal dapat menggunakan informasi akuntansi untuk memonitor kinerja agen (Kepala Daerah).

\section{Penerapan Transparansi Pelaporan keuangan}

Menurut Mahsun (2009:92) transparansi pelaporan keuangan adalah prinsip menjamin akses atau kebebasan bagi setiap orang untuk memperoleh informasi tentang penyelenggaraan pemerintah, yakni tentang kebijakan, proses pembuatan dan pelaksanaan serta hasil-hasil yang dicapai. Tujuan dari transparansi itu sendiri adalah untuk menyediakan informasi keuangan yang terbuka bagi masyarakat dalam rangka untuk mewujudkan pemerintah yang jujur dan baik. Beberapa karakteristik kualitatif laporan keuangan yang merupakan prasyarat normatif yang diperlukan agar laporan keuangan pemerintah dapat memenuhi kualitas yang dikehendaki (Kerangka Konseptual,SAP,2010). 1) Relevan, laporan keuangan bisa dikatakan relevan apabila informasi tersebut tepat waktu dan lengkap yang termuat didalamnya dapat mempengaruhi keputusan pengguna dengan membantu mengevaluasi peristiwa masa lalu, dan memprediksi masa depan, serta menegaskan atau mengerokesi hasil evaluasi masa lalu. 2)Andal, Informasi dalam laporan keuanganbebas dari pengertian yang menyesatkan dan kesalahan material, menyajikan setiap fakta secara jujur, serta dapat diverifikasi. 3)Dapat dibandingkan, Informasi yang termuat dalam laporan keuangan akan lebih berguna jika dapat dibandingkan dengan laporan keuangan periode sebelumnya atau laporan keuangan entitas pelaporan lain pada umumnya Perbandingan dapat dilakukan secara internal dan ektsernal. Perbandingan secara internal dapat dilakukan bila suatu entitas menerapkan kebijakan akuntansi yang sama dari tahun ke tahun. Perbandingan secara eksternal dapat dilakukan bila entitas yang diperbandingkan menerapkan kebijakan akuntansi yang sama. 4)Dapat dipahami, Informasi yang disajikan dalam laporan keuangan dapat dipahami oleh pengguna dan dinyatakan dana bentuk serta istilah yang disesuaikan dengan batas pemahaman para pengguna.

\section{Kompetensi Sumberdaya Manusia}

Menurut Mangkunegara kompetensi sumberdaya manusia adalah kompetensi yang berhubungan dengan keterampilan, dan kemampuan serta karakteristik kepribadian yang mempengaruhi secara langsung terhadap kinerjanya. Kompetensi sumberdaya manusia merupakan dasar seseorang untuk mencapai kinerja yang lebih tinggi dalam menyelesaikan tugasnya. Sumberdaya manusia yang tidak memiliki kompetensi tidak akan dapat menyelesaikan pekerjaannya secara efisien, efektif dan ekonomis.

\section{Tekanan Eksternal}

Isomorfisme Koersif selalu terkait dengan segala hal yang berhubungan lingkungan disekitar organisasi (Ridha dan Basuki, 2012). Isomorfisme koersif (coersive isomorphism) merupakan hasil dari tekanan formal dan informal yang diberikan pada organisasi lain dimana organisasi tergantung dengan 
harapan budaya masyarakat dimana organisasi itu menjalankan fungsinya (DiMaggio dan Powell, 1983). Kekuatan koersif adalah tekanan eksternal yang diberikan oleh pemerintah, peraturan, atau lembaga lain untuk mengadopsi struktur atau sistem (Asworth et.al, 2009). Adanya peraturan ditunjukkan untuk mengatur praktik yang ada agar menjadi lebih baik. Disisi lain, kekuatan koersif dari suatu peraturan dapat menyebabkan adanya kecenderungan organisasi untuk memperoleh atau memperbaiki legitimasi (legitimate coercion), (Scott 1987). Sehingga hanya menekankan aspek-aspek positif agar organisasi terlihat baik oleh pihak-pihak diluar organisasi (Ridha dan Basuki, 2012). Perubahan organisasi yang didasari kekuatan koersif akan menyebabkan organisasi lebih mempertimbangkan pengaruh politik dari pada teknis (Ashworth,2009).

\section{Komitmen Organisasi}

Menurut Robbins dan Judge (2015) komitmen organisasi merupakan suatu keadaan dimana karyawan memihak suatu organisasi tertentu dan tujuan-tujuannya serta memiliki keinginan untuk bertahan sebagai anggota di dalam organisasi tersebut.

\section{Sistem Pengendalian Intern}

Menurut I Gusti Agung Rai (2008: 283) Sistem pengendalian intern adalah kebijakan dan prosedur yang dirancang untuk memberikan keyakinan yang memadai bagi manajemen bahwa organisasi mencapai tujuan dan sasarannya.. Karakteristik yang baik akan mendukung terciptanya pengendalian internal yang efektif. Rencana organisasi, sistem otoritas, dan prosedur pencatatan yang tepat, praktek yang sehat serta pengamat kualitas yang cocok harus terintegrasi dengan baik dalam pelaksanaan tugasnya. Kelancaran pekerjaan akan memudahkan pengendalian internal dalam melaksanakan suatu tujuan organisasi.

\section{Kerangka Pemikiran dan Pengembangan Hipotesis}

\section{Pengaruh Kompetensi Sumberdaya Manusia terhadap Penerapan Transparansi Pelaporan Keuangan Pemerintah Daerah.}

Penerpan Transparansi Laporan Keuangan merupakan sebuah tuntutan terhadap organisasi publik karena digunakan oleh para stakeholders dalam mengambil keputusan. Laporan keuangan merupakan output organisasi yang dihasilkan oleh perangkat dalam organisasi tersebut melalui sebuah sistem yang telah diatur. Dalam sebuah sistem, sumber daya manusia adalah perangkat dalam menjalankan sistem tersebut yang menetukan hasil yang didapat dari sistem tersebut. Konpetensi sumber daya manusia adalah perangkat dalam menjalankan organissasi public dalam ini kompetensi sumber daya manusia meruapakan perangkat dalam menerapkan transparansi pelaporan keuangan organisasi public. Penerapan transparansi pelaporan kuangan yang tinggi sangat dipengaruhi oleh kompetensi sumberdaya manusia di dalam organisasi tersebut. Dapat dikatakan bahwa kompetensi sumberdaya manusia berpengaruh signifikan positif terhadap transpransi pelaporan keuangan.

Widodo (2001:15) menyatakan bahwa terwujudnya penerapan transparansi pelaporan keuangan membutuhkan mutu sumber daya manusia yang bisa mengaplikasikan logika akuntansi pada pencatatan laporan keuangan Pemerintah Daerah. Mutu sumber daya manusia merupakan modal utama untuk melaksanakan tugas dan tanggung jawab yang diberikan dan atau bekal pendidikan, pelatihan dan pengalaman yang cukup memadai untuk membuat pencatatan laporan keuangan.

Hal ini sejalan dengan penelitian yang dilakukan deddi Fardian(2014) yang menyatakan bahwa kompetensi sumber daya manusia berpengaruh terhadap penerapan transparansi pelaporan keuangan pemerintah daerah. Hal ini memperlihatkan semakin berkompeten aparatur perangkat daerah maka akan dapat menerapkan kebijakan transparansi pelaporan keuangan dengan baik.

$\mathrm{H}_{1}$ : kompetensi sumberdaya manusia berpengaruh terhadap penerapan transparansi pelaporan keuangan pemerintah daerah

\section{Pengaruh Tekanan Eksternal terhadap Penerapan Transparansi Pelaporan Keuangan Pemerintah daerah}

Transparansi pelaporan keuangan mengharuskan organisasi untuk menyajikan laporan keuangan yang bebas dari salah material dan informasi yang bias kepada pihak luar. Hlitu sesuai dengan konsep keterandalan (reability) dimana informasi dalam laporan keuangan harus bebas dari pengertian menyesatkan dan kesalahan material, menyajikan setiap fakta secara jujur, serta dapat diverifikasi (PP No. 24/2005, Lampiran II: Kerangka Konseptual Akuntansi Pemerintah No.35). Tekanan eksternal merupakan tekanan yang berasal dari legislatif, lembaga swadaya masyarakat, partai politik dan media massa yang kemudian menjadi pendorong untuk diterapkannya transparansi pelaporan keuangan pada pemerintah daerah. Tekanan maupun paksaan dari pihak luar mempunyai peranan yang penting terhadap transparansi kepada publik, dimana peningkatan tekanan eksternal yang terjadi akan seiring dengan peningkatan transparansi pelaporan keuangan pemerintah daerah.

Ridha dan Basuki (2012) menyatakan bahwa tekanan eksternal yang berupa undang-undang atau 
peraturan menjadi pendorong untuk diterapkannya transparansi pelaporan keuangan di pemerintahan daerah. Peraturan dan undang-undang tersebut merupakan indikator adanya tekanan eksternal dalam bentuk koersif untuk terciptanya transparansi pelaporan keuangan dan mengakibatkan penerapan transparansi pelaporan keuangan yang relatif sama antara OPD yang satu dengan yang lain.

Penelitian ini sejalan dengan penelitian yang dilakukan Sihaloho (2013), Amelia (2015) dan Sainu (2014) juga menghasilkan bahwa tekanan eksternal mempengaruhi penerapan transparansi pelaporan keuangan.Maka hipotesisnya sebagai berikut;

$\mathrm{H}_{2}$ : Tekanan eksternal berpengaruh terhadap penerapan transparansi pelaporan keuangan pemerintah daerah

\section{Pengaruh Komitmen Organisasi terhadap Penerapan Transparansi Pelaporan Keuangan Pemerintah Daerah}

Yusuf dan Syarif (2018:18) Menyatakan bahwa Komitmen dari organisasi sektor publik merupakan sikap loyalitas karyawan terhadap organisasi dengan cara tetap bertahan dalam organisasi, membantu mencapai tujuan organisasi dan tidak memiliki keinginan untuk meninggalkan organisasi dengan alasan apapun. Dengan kesiapan mengerahkan upaya yang cukup besar untuk kepentingan organisasi dalam hal keterbukaan kepada publik terkait dengan pelaporan keuangan. Komitmen organisasi merupakan rasa identifikasi (kepercayaan terhadap nilai-nilai organisasi), keterlibatan dan loyalitas karyawan yang ditunjukkan dengan bukti pengembangan komitmen pada organisasi melalui berbagai dimensi atau berbagai sumber. Transparansi pelaporan keuangan dipengaruhi oleh komitmen organisasi, karena hampir keseluruhan Organisasi Perangkat Daerah memiliki integritas dan komitmen yang tinggi dalam menerapkan transparansi pelaporan keuangan. Dalam pelaporan keuangan, OPD tidak hanya melaporkan informasi yang hanya bersifat positif berupa pencapaian, akan tetapi juga menginformasikan berupa ketidaktercapaian dari OPD tersebut. Adanya peraturan atau Undang-Undang sebagai pendorong untuk diterapkannya transparansi pelaporan keuangan. Namun dalam jangka panjang penerapan transparansi pelaporan keuangan membutuhkan komitmen dari manajemen OPD untuk terus belajar dan memahami serta menyesuaikan praktiknya dengan peraturan yang baru.

Hal ini sejalan dengan penelitian yang dilakukan oleh Ayu (2018) menunjukkan bahwa semakin tinggi Komitmen Organisasi, maka Penerapan Transparansi Pelaporan Keuangan semakin baik.
$\mathrm{H}_{3}$ : komitmen organisasi berpengaruh terhadap penerapan transparansi pelaporan keuangan pemerintah daerah

\section{Pengaruh Sistem Pengendalian Intern terhadap Penerapan Transparansi Pelaporan Keuangan Pemerintah Daerah}

Mahmudi (2007:182) menyatakan bahwa untuk menghasilkan laporan keuangan pemerintah daerah diperlukan proses dan tahap-tahap yang harus dilalui yang diatur dalam sistem akuntansi pemerintah daerah. Sistem akuntansi didalamnya mengatur tentang sistem pengendalian intern (SPI), kualitas dan transparansi pelaporan keuangan sangat dipengaruhi oleh bagus tidaknya sistem pengendalian intern yang dimiliki pemerintah daerah. Indra Bastian (2006) mendefinisikan pengendalian internal sebagaisuatu proses yang dijalankan oleh eksekutif (kepala daerah, instansi/dinas, dan segenap personel) yang didesain untuk memberikan keyakinan yang memadai tentang pencapaian tiga golongan tujuan yang terdiri atas keandalan laporan keuangan, kepatuhan terhadap hukum, dan peraturan yang berlaku serta efektivitas dan efisiensi operasi. OPD sebagai level pelaksana pemerintah daerah mengemban tugas untuk dapat memberikan keyakinan kepada masyarakat bahwa tujuan organisasi yang terdiri atas keandalan laporan keuangan, kepatuhan terhadap hukum, dan peraturan yang berlaku serta efektivitas dan efisiensi operasi dapat tercapai. Dalam menjalankan proses pengendalian di dalam tubuh pemerintahan, pemerintah daerah diharapkan mampu terbuka dan transparan dalam melakukan setiap kewajibannya.

Penelitian yang dilakukan oleh Benny (2016), menyatakan bahwa berpengaruh positif terhadap penerapan transparansi pelaporan keuangan, berupa sistem untuk memberikan keyakinan memadai tentang pencapaian tujuan efektifitas dan efisiensi operasi, keandalan pelaporan keuangan, kepatuhan terhadap hukum dan peraturan yang berlaku sehingga menjadi pemicu diterapkannya transparansi pelaporan keuangan

$\mathrm{H}_{4}$ : sistem pengendalian intern berpengaruh terhadap penerapan transparansi pelaporan keuangan

\section{METODE PENELITIAN}

\section{Lokasi dan Waktu Penelitian}

Lokasi pada penelitian ini adalah Organisasi Perangkat Daerah (OPD) di Kabupaten Rokan Hilir.

\section{Populasi dan Sampel}

Populasi dalam penelitiaan ini adalah seluruh organisasi perangkat daerah (OPD) yang ada di kabupaten rokan hilir sebanyak 45 yang terdiri dari inspektorat, sekretaris daerah, sekretaris DPRD, Badan, Dinas dan Kecamatan. Sedangkan Penentuan 
jumlah sampel yang digunakan dalam penelitian ini adalah berdasarkan metode slovin sebagai alat ukur untuk menghitung ukuran sampel. Sehingga jumlah sampel yang diambil dalam penelitian ini adalah sebanyak 40 OPD. Dimana untuk satu OPD diambil 3 responden dengan kriteria Kepala OPD, Bendahara, dan KaSubbag Keuangan, sehingga jumlah responden dalam penelitian ini sebanyak 120 .

\section{Jenis dan Sumber Data}

Jenis data yang digunakan dalam penelitian ini adalah kuantitatif, yaitu berupa nilai atau skor atas jawaban yang diberikan oleh responden terhadap pertanyaan yang ada dalam kuesioner. Adapun sumber data dalam penelitian ini yaitu data primer.

\section{Definisi Operasional Variabel dan Pengukuran Penelitian}

Variabel independen disebut juga sebagai variabel bebas. Variabel bebas adalah variabel yang mempengaruhi atau menjadi sebab perubahan atau timbulnya variabel dependen (Sugiono, 2012:59). Dalam penelitian ini, variebel independenya adalah:

\section{Kompetensi Sumberdaya Manusia}

Indikator yang digunakan untuk mengukur kompetensi sumberdaya manusia menurut Hutapea dan Nuriana (2008) yaitu; 1)Pengetahuan (knowledge) yang berkaitan dengan pekerjaan yang meliputi, 2) Keterampilan atau keahlian (skill) individu meliputi, dan 3)sikap kerja.

\section{Tekanan Eksternal}

Untuk mengukur tekanan eksternal dapat digunakan indikator yang diadopsi dari Ridha dan Basuki (2012) yaitu : 1)Terbitnya undang-undang dan peraturan tentang transparansi; 2)Tuntutan pihakpihak terkait; 3)Tekanan media massa tentu; 4)Semakin meningkatnya kritik dari masyarakat atas penerapan laporan keuangan; 5)Perhatian lembaga kemasyarakatan.

\section{Komitmen Organisasi}

Indikator yang digunakan untuk mengukur komitmen organisasi menurut Robbins dan Judge (2015) yaitu; 1)Komitmen Afektif (keyakinan terhadap tujuan organisasi, perasaan memiliki organisasi); 2)Komitmen Keberlanjutan (mempertahakan keanggotaan organisasi, kesetiaan dalam organisasi); 3)Komitmen Normative (kesediaan mengerahkan upaya atas nama organisasi).

\section{Sistem Pengendalian Intern}

Indikator yang digunakan untuk mengukur sistem pengendalian intern menurut PP 60 Tahun 2008 yaitu; 1)lingkungan pengendalian, 2)penilaian resiko, 3)kegiatan pengendalian, 4)informasi dan komunikasi, 5)pemantauan.

\section{VARIABEL DEPENDEN}

\section{Penerapan Transparansi Pelaporan Keuangan}

Menurut Kristianten (2006:45) menyebutkan transparansi pelaporan keuangan adalah keterbukaan pemerintah dalam memberikan informasi yang terkait dengan aktifitas pengelolaan sumber daya publik kepada pihak yang membutuhkan yaitu masyarakat.

Adapun indikator menurut Kristianten (2006:73) menyebutkan bahwa transparansi dapat diukur melalui beberapa indikator yaitu; 1)Kesediaan dan aksesibilitas dokumen; 2)Kejelasan dan kelengkapan informasi; 3)Keterbukaan proses; 4)Kerangka regulasi yang menjamin transparansi.

\section{Metode Analisis Data}

Hasil penelitian dan kesimpulan penelitian yang berupa atau pemecahan masalah penelitian, dibuat berdasarkan proses pengujian data yang meliputi pemilihan, pengumpulan dan analisis data. Proses analisis data merupakan usaha untuk memperoleh jawaban permasalahan penelitian. Dalam penelitian ini Analisis data dalam penelitian ini menggunakan pendekatan Partial Least Square (PLS) dalam hal ini akan menggunakan software WarpPLS 5.0

\section{Partial Least Square (PLS)}

Menurut Latan dan Ghozali (2017:3) Partial Least Squares Equation Modeling (PLS-SEM) merupakan metode alternatif untuk model persamaan struktural SEM yaitu untuk menguji secara simultan hubungan antara konstruk laten dalam hubungan linear ataupun non-linear dengan banyak indikator baik berbentuk mode A (refleksi), mode B (formatif) dan atau mode M (MIMIC).

Model hubungan semua variabel laten dalam PLS terdiri dari tiga ukuran, yaitu : (1) outer model (measurement model) yang menspesifikasi hubungan antara indikator dengan variabel latennya ;

(2) inner model (structural model) yang menspesifikasi hubungan antar variabel laten berdasarkan pada teori substantif ;

(3) estimasi nilai dari variabel laten (weight relation).

Estimasi parameter dalam PLS adalah metode kuadrat terkecil. Estimasi parameter didalam PLS meliputi 3 hal, yaitu :

1. Weight estimate yang digunakan untuk menciptakan skor variabel laten

2. Estimasi jalur (path estimate) yang menghubungkan variabel laten dengan variabel 
laten lainnya dan estimasi loading antara variabel laten dengan indikatornya.

3. Means dan lokasi parameter (nilai konstanta regresi, intersep) untuk indicator dan variabel laten.

\section{Statistik Deskriptif}

Statistik deskriptif untuk memberikan gambaran atau deskripsi dari variabel penelitian. Statistik deskriptif berhubungan dengan metode pengelompokkan, peringkasan, dan penyajian data dalam cara yang lebih infromatif (Santosa, 2005). Data statistik dapat disajikan dengan menggunakan tabel statistic descriptive yang memaparkan nilai minimum, nilai maksimum, nilai rata-rata (mean), dan standar deviasi (standard deviation). Mean digunakan untuk memperkirakan besar rata-rata populasi yang diperkirakan dari sampel. Standar deviasi digunakan untuk menilai disperse rata-rata dari sampel. Maksimum dan minimum digunakan untuk melihat nilai minimum dan maksimum dari sampel. Semuanya diperlukan untuk melihat gambaran keseluruhan dari sampel yang berhasil dikumpulkan dan memenuhi syarat untuk dijadikan sampel penelitian.

\section{Evaluasi Model Pengukuran (Outer Model)}

\section{Convergent Validity}

Convergent validity merupakan tingkatan sejauh mana hasil pengukuran suatu konsep menunjukkan korelasi positif dengan hasil pengukuran konsep lain yang secara teoritis harus berkorelasi positif. Validitas konvergen merupakan bagian dari measurement model yang dalam SEM-PLS biasanya disebut sebagai outer model. Terdapat dua kriteria untuk menilai outer model yang memenuhi syarat validitas konvergen yaitu (1) loading harus di atas 0,70 dan (2) nilai p signifikan yaitu $\mathrm{p}<0,05$ (Sholihin dan Ratmono, 2013: 65). Dengan syarat tersebut, pengukuran konstruk yang diteliti dianggap telah memenuhi syarat validitas konvergen.

\section{Discriminant Validity}

Discriminant validity merupakan tingkatan sejauh mana hasil pengukuran suatu konsep mampu membedakan diri dengan hasil pengukuran konsep lain secara teoritis memang harus berbeda. Validitas diskriminan juga merupakan bagian dari outer model. Syarat untuk memenuhi syarat validitas diskriminan ini adalah hasil dalam indicators loading and cross loadings menunjukkan bahwa loading ke konstruk lain (cross-loading) bernilai lebih rendah daripada loading blok indikator ke konstruk variabel.

\section{Composite Reliability}

Bagian ketiga dari outer model yaitu composite reliability. Penilaian dari composite reliability ini dilakukan dengan melihat output dari view latent variable coefficients. Dari output ini, maka kriteria dilihat dari dua hal yaitu composite reliability dan cronbach's alpha. Nilai composite reliability dan cronbach's alpha yang nilainya >0,70 dapat dikatakan reliabel (Sholihin dan Ratmono, 2013: 73).

\section{Evaluasi Model Struktural (Inner Model)}

Inner model menentukan spesifikasi hubungan antara konstruk laten dengan konstruk laten lainnya, Evaluasi ini meliputi uji kecocokan model (model fit), path coefficient, dan $\mathrm{R}^{2}$. Uji kecocokan model dilakukan sebelum menguji signifikansi path coefficient dan $\mathrm{R}^{2}$. Uji model fit ini digunakan untuk mengetahui suatu model memiliki kecocokan dengan data. Pada uji kecocokan model terdapat 3 indeks pengujian, yaitu average path coefficient (APC), average $R$-squared (ARS) dan average varians factor (AVIF). APC dan ARS diterima dengan syarat $\mathrm{p}-$ value $<0.05$ dan AVIF lebih kecil dari 5. Selanjutnya hasil path coefficient dan $\mathrm{R}^{2}$ dapat dilihat pada direct effect, hasil dari pengolahan data. Path coefficient digunakan untuk mengetahui seberapa besar nilai koefisien jalur. $\mathrm{R}^{2}$ dapat di lihat pada effect size digunakan untuk mengetahui seberapa besar pengaruh variabel independen mempengaruhi variabel dependen.

\section{HASIL PENELITIAN DAN PEMBAHASAN}

\section{Analisis Statistik Deskriptif}

\section{Tabel 1 Statistik Deskriptif}

\begin{tabular}{|l|l|l|l|l|l|}
\hline Variabel & N & $\begin{array}{l}\text { M } \\
\text { M }\end{array}$ & MEAN & Std. \\
& & N & X & & Deviasi \\
\hline KSDM & 111 & 3 & 5 & 4,3877 & 0,4838 \\
\hline TE & 111 & 2 & 5 & 4,0025 & 0,7473 \\
\hline KO & 111 & 3 & 5 & 4,1557 & 0,5706 \\
\hline SPI & 111 & 4 & 5 & 4,3630 & 0,2525 \\
\hline PTPK & 111 & 3 & 5 & 4,4785 & 0,4673 \\
\hline
\end{tabular}

Sumber : Data Olahan WarpPLS(2020)

\section{Evaluasi Measurement (outer) Model}

\section{Convergent Validity}

\section{Tabel 2 Hasil Uji Convergent Validity}

\section{Loading Factor}

\begin{tabular}{|l|l|l|l|l|l|}
\hline X1 & X2 & X3 & X4 & Y & P \\
Value
\end{tabular}




\begin{tabular}{|l|l|l|l|l|l|l|}
\hline I1 & 0.674 & 0.809 & 0.780 & 0.521 & 0.775 & $<0.001$ \\
\hline I2 & 0.821 & 0.832 & 0.775 & 0.874 & 0.806 & $<0.001$ \\
\hline I3 & 0.731 & 0.849 & 0.624 & 0.774 & 0.934 & $<0.001$ \\
\hline I4 & 0.786 & 0.890 & 0.639 & 0.899 & 0.611 & $<0.001$ \\
\hline I5 & 0.814 & & 0.778 & 0.723 & 0.621 & $<0.001$ \\
\hline I6 & 0.795 & & 0.683 & 0.602 & 0.833 & $<0.001$ \\
\hline I7 & & & 0.743 & 0.832 & 0.808 & $<0.001$ \\
\hline I8 & & & & 0.703 & 0.721 & $<0.001$ \\
\hline I9 & & & & 0.751 & 0.737 & $<0.001$ \\
\hline I10 & & & & 0.798 & & $<0.001$ \\
\hline I11 & & & & 0.805 & & $<0.001$ \\
\hline I12 & & & & 0.926 & & $<0.001$ \\
\hline I13 & & & & 0.855 & & $<0.001$ \\
\hline I14 & & & & 0.725 & & $<0.001$ \\
\hline
\end{tabular}

Sumber: Data Olahan WarpPLS (2020)

Berdasarkan tabel diatas, kelima konstruk telah memenuhi convergent validity dengan syarat loading harus diatas 0.70 dan nilai $\mathrm{p}$ signifikan yaitu $\mathrm{p}$ $<0.05$. seperti Kompetensi sumberdaya manusia (KSDM), tekanan eksternal (TE), komitmen organisasi (KO) dan sistem pengendalian intern (SPI), masing-masing memiliki nilai loading $>0,70$ dan berada disekitar >0,5-0,6 dapat dikatakan valid serta P-Value dari setiap konstruk adalah $<0,001$ atau dengan kata lain signifikan.

\section{Discriminant Validity}

\section{Tabel 3 Hasil Uji Discriminan Validity}

Correlations among l.vs. with sq. rts. of AVEs

\begin{tabular}{|c|c|c|c|c|c|}
\hline \multicolumn{6}{|c|}{ a } \\
\hline & X1 & $\mathrm{X} 2$ & $\mathbf{X 3}$ & X4 & $\mathbf{Y}$ \\
\hline X1 & $\begin{array}{l}(0.772 \\
)\end{array}$ & 0.397 & 0.383 & 0.344 & 0.293 \\
\hline $\mathrm{X} 2$ & 0.397 & $\begin{array}{l}(0.845 \\
)\end{array}$ & 0.464 & 0.316 & 0.515 \\
\hline $\mathbf{X 3}$ & 0.383 & 0.464 & $\begin{array}{l}(0.720 \\
)^{2}\end{array}$ & 0.271 & 0.445 \\
\hline $\mathrm{X4}$ & 0.344 & 0.316 & 0.271 & $\begin{array}{l}(0.743 \\
{ }^{2}\end{array}$ & 0.092 \\
\hline
\end{tabular}

\begin{tabular}{|l|l|l|l|l|l|}
\hline $\mathbf{Y}$ & 0.293 & 0.515 & 0.445 & & $(0.720$ \\
\hline
\end{tabular}
Sumber: Data Olahan WarpPLS(2020)

Berdasarkan tabel diatas, keseluruhan indikator telah memenuhi kriteria validitas diskriminan. Hal tersebut ditunjukkan dengan nilai loading setiap konstruk lebih tinggi daripada cross loading terhadap konstruk lainnya, yaitu untuk nilai kompetensi sumberdaya manusia (KSDM) sebesar 0.772, tekanan eksternal (TE) sebesar 0.845, komitmen organisasi (KO) sebesar 0.720, sistem pengendalian intern (SPI) sebesar 0.743 dan penerapan transparansi pelaporan keuangan (PTPK) sebesar 0.720 .

\section{Composite Reability}

Tabel 4 Hasil Uji Reabilitas

\begin{tabular}{|l|c|c|}
\multicolumn{2}{|c}{ Composite Reliability } \\
\hline Variabel & Composite & $\begin{array}{c}\text { Cronbach's } \\
\text { alpha }\end{array}$ \\
\hline KSDM & 0.898 & 0.863 \\
\hline TE & 0.909 & 0.866 \\
\hline KO & 0.882 & 0.843 \\
\hline SPI & 0.970 & 0.855 \\
\hline PTPK & 0.904 & 0.880 \\
\hline
\end{tabular}

Sumber: Data Olahan WarpPLS (2020)

Berdasarkan tabel diatas dapat disimpulkan bahwa masing-masing konstruk telah memenuhi kriteria reliabel. Hal ini ditunjukkan dengan nilai composite reliability dan cronbach's alpha setiap konstruk diatas 0.70. untuk kompetensi sumberdaya manusia (KSDM) memiliki nilai sebesar 0.898 dan 0.863, tekanan eksternal (TE) sebesar 0.909 dan 0.866 , komitmen organisasi (KO) sebesar 0.882 dan 0.843, sistem pengendalian intern (SPI) sebesar 0.970 dan 0.855 , penerapan transparansi pelaporan keuangan (PTPK) memiliki nila composite dan cronbach's alpha sebesar 0.904 dan 0.880 .

\section{Evaluasi Model Struktural (Inner Model)}

\section{Gambar 1 output general SEM analysis Result}

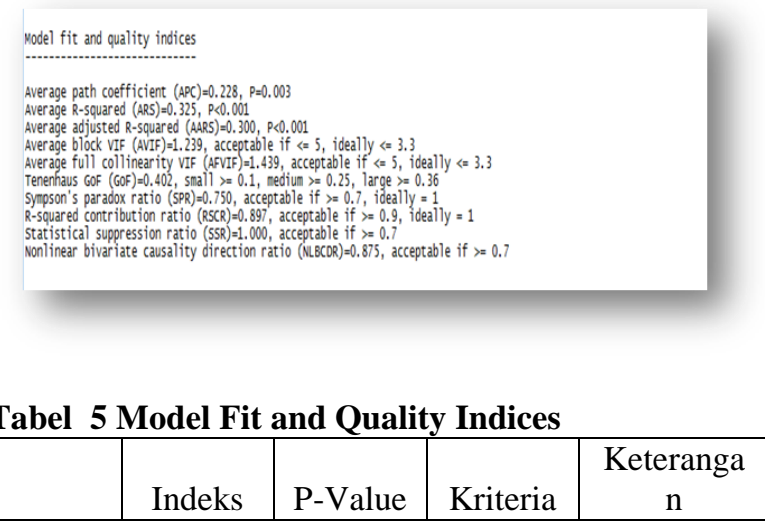




\begin{tabular}{|l|c|c|c|c|} 
APC & 0,228 & 0,003 & $\mathrm{P}<0,05$ & Diterima \\
\hline ARS & 0,325 & $<0,001$ & $\mathrm{P}<0,05$ & Diterima \\
\hline AARS & 0,300 & $<0,001$ & $\mathrm{P}<0,05$ & Diterima \\
\hline AVIF & 1,439 & & $\begin{array}{c}\text { AVIF } \\
<5\end{array}$ & Diterima \\
\hline
\end{tabular}

Sumber: Data Olahan WarpPLS (2020)

Berdasarkan hasil tabel diatas, nilai indeks dari APC adalah 0.228 dengan P-Value sebesar 0.003, untuk nilai indeks ARS adalah sebesar 0.135 dengan P-Value <0.001, serta nilai indeks AARS adalah sebesar 0.300 dengan P-Value sebesar $<0.001$. Maka dari itu, APC, ARS dan AARS telah memenuhi kriteria yang mana memiliki P-Value <0.05. Selanjutnya nilai AVIF adalah sebesar 1.439 yang menunjukkan bahwa AVIF adalah lebih kecil dari 5, maka dapat disimpulkan bahwa model structural (inner model) dapat diterima.

Tabel 6 R-squared Coefficients

\begin{tabular}{|l|l|}
\hline & $\begin{array}{l}\text { R-squared } \\
\text { Coefficients }\end{array}$ \\
\hline $\begin{array}{l}\text { Kompetensi Sumber Daya } \\
\text { Manusia }\end{array}$ & \\
\hline Tekanan Eksternal & \\
\hline Komitmen Organisasi & \\
\hline Sistem Pengendalian Intern & 0,325 \\
\hline $\begin{array}{l}\text { Penerapan Transparansi } \\
\text { Pelaporan Keuangan }\end{array}$ & \\
\hline
\end{tabular}

Sumber: Data Olahan WarpPLS (2020)

Berdasarkan tabel di atas, dapat diketahui bahwa nilai $r$-square $\left(\mathrm{R}^{2}\right)$ dari variabel penerapan transparansi pelaporan keuangan adalah sebesar 0,325. Hasil ini menunjukkan bahwa kemampuan variabel kompetensi sumberdaya manusia, tekanan eksternal, komitmen organisasi dan sistem pengendalian intern dalam menjelaskan variabel penerapan transparansi pelaporan keuangan adalah sebesar $33 \%$, sedangkan sisanya $67 \%$ dijelaskan oleh variabel lain yang tidak diteliti dalam penelitian ini.

\section{HASIL PENGUJIAN HIPOTESIS DAN PEMBAHASAN}

Pengujian hipotesis dilakukan untuk membuktikan kebenaran dugaan penelitian atau hipotesis. Hasil korelasi antar konstruk dapat dilihat dengan tingkat signifikansinya. Tingkat signifikasinya yang dipakai dalam penelitian ini adalah sebesar $5 \%$. Sehingga sebagai dasar pengambilan keputusan jika $\mathrm{P}$ Value $\leq 0.05$, maka hipotesis diterima. Jika P-Value $\geq 0.05$ maka hipotesis ditolak.
Tabel 7 Hasil Uji Hipotesis

\begin{tabular}{|c|c|c|c|c|c|}
\hline $\begin{array}{c}\text { Hipot } \\
\text { esis }\end{array}$ & $\begin{array}{c}\text { Indepe } \\
\text { nden }\end{array}$ & $\begin{array}{c}\text { Depen } \\
\text { den }\end{array}$ & $\begin{array}{c}\text { Koefi } \\
\text { sien } \\
\text { Regre } \\
\text { si }\end{array}$ & $\begin{array}{c}\text { P } \\
\text { ue }\end{array}$ & $\begin{array}{c}\text { Keput } \\
\text { usan }\end{array}$ \\
\hline H1 & KSDM & PTPK & 0.169 & $\begin{array}{c}0.03 \\
3\end{array}$ & $\begin{array}{c}\text { Diteri } \\
\text { ma }\end{array}$ \\
\hline H2 & TE & PTPK & 0.416 & $\begin{array}{c}<0.0 \\
01\end{array}$ & $\begin{array}{c}\text { Diteri } \\
\text { ma }\end{array}$ \\
\hline H3 & KO & PTPK & 0.170 & $\begin{array}{c}0.03 \\
2\end{array}$ & $\begin{array}{c}\text { Diteri } \\
\text { ma }\end{array}$ \\
\hline H4 & SPI & PTPK & 0.157 & $\begin{array}{c}0.04 \\
4\end{array}$ & $\begin{array}{c}\text { Diteri } \\
\text { ma }\end{array}$ \\
\hline
\end{tabular}

Sumber : Data Olahan WarpPLS(2020)

\section{Gambar 2 Model Struktural}

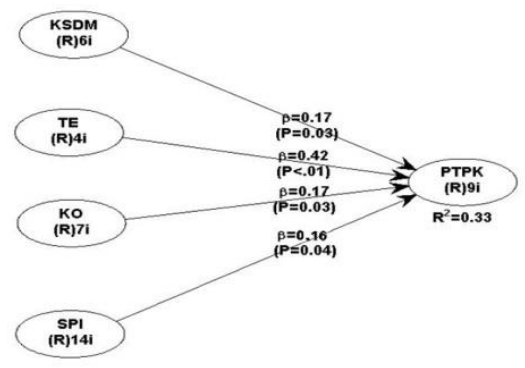

\section{Hasil Uji Hipotesis Pertama}

Berdasarkan hasil pengujian hipotesis pertama yang telah dilakukan, diketahui bahwa nilai p- value adalah 0.033 dengan nilai signifikan P-Value $<0.05$ dan nilai beta $(\beta)$ sebesar 0.169. hal ini menunjukkan bahwa hipotesis diterima, Sehingga hasil penelitian ini menyatakan bahwa kompetensi sumber daya manusia berpengaruh terhadap penerapan transparansi pelaporan keuangan. Hasil ini menunjukkan bahwa kompetensi yang dimiliki oleh sumber daya manusia yang ada pada organisasi perangkat daerah kab. rokan hilir dapat memberikan kontribusi dalam upaya meningkatkan pencapaian tujuan organisasi itu sendiri. upaya peningkatan kompetensi SDM dapat dilakukan melalui pertama dalam hal pengelolaan dan pelaporan keuangan dibutuhkan skill yang bagus, dimana sumberdaya manusia tersebut harus mampu melaksanakan tugas dan tanggungjawab yang diberikan oleh organisasi kepada pegawai/aparatur dengan lebih baik dan maksimal, Kedua knowledge, SDM harus memiliki pengetahuan yang luas mengenai cara pengelolaan dan pelaporan keuangan yang baik mulai dari perencanaan sampai pertanggungjawaban agar pelaporan keuangan bisa berjalan sesuai dengan prosedur dan mencerminkan pelaporan yang transparan. Ketiga 
attitude, sikap Profesionalisme merupakan suatu hal yang terkait dengan integritas dan kompetensi sumberdaya manusia di organisasi itu sendiri. Hal ini dimaksudkan agar aparatur dapat mengerti dan paham dengan apa yang dikerjakan dan tujuan organisasi. sehingga semakin berkompeten sumber daya manusia/aparatur dibidang nya, maka semakin baik pula penerapan transparansi pelaporan keuangan.

Hal ini sesuai dengan teori yang dikemukakan oleh Hutapea dan Toha (2008:8) mengungkapkan ada beberapa komponen dalam pembentukan kompetensi sumber daya manusia yaitu; 1) pengetahuan (knowledge), 2) keterampilan (skill) dan 3)sikap (attitude). Dan mendukung penelitian yang dilakukan oleh Fardian (2014) yang menyatakan bahwa kompetensi sumber daya manusia berpengaruh signifikan terhadap penerapan transparansi pelaporan keuangan.

\section{Hasil Uji Hipotesis Kedua}

Berdasarkan hasil pengujian hipotesis kedua yang telah dilakukan, diketahui bahwa nilai $\mathrm{p}$ - value adalah $<0.001$ dengan nilai signifikan P-Value $<0.05$ dan nilai beta $(\beta)$ sebesar 0.416 . hal ini menunjukkan bahwa hipotesis diterima, Sehingga hasil penelitian ini menyatakan bahwa tekanan eksternal berpengaruh terhadap penerapan transparansi pelaporan keuangan. Hasil ini menunjukan bahwa tekanan eksternal merupakan gambaran mengenai satu persoalan tersendiri yang dihadapi organisasi pemerintah kab. rokan hilir. Dimasa otonomi daerah saat ini tekanan eksternal hadir untuk menekankan setiap penyelenggaraan pemerintah kab. rokan hilir mengenai penting nya untuk menerapkan transparansi pelaporan keuangan dalam mengelola sumber daya regional, meningkatkan kualitas layanan publik dan kesejahteraan rakyat.

hal ini dimaksudkan karena adanya tekanan/tuntutan dari luar seperti perubahan regulasi, kritikan masyarakat dan tuntutan partai politik, maka pemerintah kab. rokan hilir harus dapat menerapkan kebijakan transparansi pelaporan keuangan dipemerintahan dan dapat mengatur praktik yang ada agar menjadi lebih baik.

hal ini sesuai dengan teori Asworth et.al, (2009) Kekuatan koersif adalah tekanan eksternal yang diberikan oleh pemerintah, peraturan, atau lembaga lain untuk mengadopsi struktur atau sistem. dan mendukung penelitian sebelumnya Ridha dan Basuki (2012) menyatakan bahwa tekanan eksternal berpengaruh terhadap penerapan transparansi pelaporan keuangan. tekanan eksternal berupa undang-undang atau peraturanmenjadi pendorong untuk diterapkannya transparansi pelaporan keuangan di wilayah provinsi D.I. Yogyakarta.

\section{Hasil Uji Hipotesis Ketiga}

Berdasarkan hasil pengujian hipotesis ketiga yang telah dilakukan, diketahui bahwa nilai $\mathrm{p}$ - value adalah 0.032 dengan nilai signifikan $\mathrm{P}$-Value $<0.05$ dan nilai beta $(\beta)$ sebesar 0.170 . hal ini menunjukkan bahwa hipotesis diterima, Sehingga hasil penelitian ini menyatakan bahwa komitmen organisasi berpengaruh terhadap penerapan transparansi pelaporan keuangan. Karena setiap anggota organisasi harus mengimplementasikan tujuan dalam organisasi dengan kesadaran penuh khususnya bagi anggota penatausahaan keuangan,sehingga dapat menciptakan tata kelola pemerintahan yang baik. Dalam penyusunan laporan keuangan dan penggunaan dana masyarakat juga anggota dalam organisasi sektor publik harus memiliki komitmen yang tinggi. Dimana salah satu karakteristik komitmen organisasi adalah kemauan yang kuat untuk berusaha atau bekerja keras untuk organisasi, keinginan untuk tetap menjadi anggota organisasi. Jadi dapat dikatakan apabila anggota organisasi bekerja dengan baik, maka akan tercipta penerapan transparansi pelaporan keuangan yang sesuai dengan standar yang berlaku dan penggunaan dana masyarakat yang terbebas dari masalah kecurangan maupun penyelewengan. Sehingga semakin berkomitmen aparatur dalam mencapai tujuan suatu organisasi, maka semakin baik pula penerapan transparansi pelaporan keuangan dilakukan.

Hal ini sesuai dengan teori yang dikemukakan oleh Robbins dan Judge (2015) yang mengungkapkan komitmen organisasi merupakan suatu keadaan dimana karyawan memihak suatu organisasi tertentu dan tujuan-tujuannya, serta memiliki keinginan untuk bertahan sebagai anggota didalam organisasi tersebut. Dan penelitian ini mendukung penelitian yang sebelumnya Ayu (2018) yang menyatakan bahwa komitmen organisasi berpengaruh terhadap penerapan transparansi pelaporan keuangan.

\section{Hasil Uji Hipotesis Keempat}

Berdasarkan hasil pengujian hipotesis keempat yang telah dilakukan, diketahui bahwa nilai p- value adalah 0.044 dengan nilai signifikan P-Value $<0.05$ dan nilai beta $(\beta)$ sebesar 0.157. hal ini menunjukkan bahwa hipotesis diterima, Sehingga hasil penelitian ini menyatakan bahwa sistem pengendalian intern berpengaruh terhadap penerapan transparansi pelaporan keuangan.

Untuk mencapai sistem pelaporan keuangan yang lebih transparan, OPD kab. rokan hilir sebagai pemerintah daerah telah menyelenggarakan kegiatan pengendalian atas keseluruhan kegiatan di instansi 
masing-masing. Dengan demikian penyelenggaraan kegiatan pada suatu Instansi Pemerintah, mulai dari perencanaan, pelaksanaan, pengawasan, sampai dengan pertanggungjawaban, telah dilaksanakan secara tertib, terkendali, serta efisien dan efektif. Hal ini akan menciptakan laporan keuangan yang transparan, pengamanan aset negara serta menjamin ketaatan dan kepatuhan setiap instansi terhadap peraturan perundang-undangan. Sehingga apabila semakin tinggi sistem pengendalian intern yang dilakukan oleh pemerintah, maka akan semakin baik pula penerapan transparansi pelaporan keuangan dilakukan.

Hal ini sesuai dengan PP No 60 tahun 2008 yang mendefinisikan sistem pengendalian intern sebagai "proses yang integral pada tindakan dan kegiatan yang dilakukan secara terus menerus oleh pimpinan dan seluruh pegawai untuk memberikan keyakinan yang memadai atas tercapainya tujuan organisasi melalui kegiatan yang efektif dan efisien, keandalan laporan keuangan, pengamanan aset negara, dan ketaatan terhadap peraturan perundangundangan." Penelitian ini mendukung penelitian sebelumny oleh Benny (2016), menyatakan bahwa berpengaruh positif terhadap penerapan transparansi pelaporan keuangan, berupa sistem untuk memberikan keyakinan memadai tentang pencapaian tujuan efektifitas dan efisiensi operasi, keandalan pelaporan keuangan, kepatuhan terhadap hukum dan peraturan yang berlaku sehingga menjadi pemicu diterapkannya transparansi pelaporan keuangan.

\section{KESIMPULAN DAN SARAN}

\section{Kesimpulan}

Penelitian ini bertujuan untuk mengetahui pengaruh kompetensi sumberdaya manusia, tekanan eksternal, komitmen organisasi, dan sistem pengendalian intern terhadap penerapan transparansi pelaporan keuangan. responden penelitian ini sejumlah 120 orang yang bekerja di organisasi perangkat daerah kabupaten rokan hilir. Untuk menganalisis hubungan antar variabel, peneliti menggunakan Warp PLS 5.0. berdasarkan analisis dan pembahasan pada bagian sebelumnya, maka ditarik kesimpulan;

1. Kompetensi Sumberdaya Manusia berpengaruh terhadap penerapan Transparansi Pelaporan Keuangan

2. Tekanan Eksternal berpengaruh terhadap Penerapan Transparansi Pelaporan Keuangan

3. Komitmen Organisasi berpengaruh terhadap Penerapan Transparansi Pelaporan keuangan

4. Sistem Pengendalian Intern berpengaruh terhadap Penerapan Transparansi Pelaporan Keuangan

\section{Keterbatasan}

1. Hasil penelitian ini tidak dapat digeneralisasikan pada lembaga-lembaga lainnya. Hal ini disebabkan kondisi di beberapa OPD berbeda satu sama lain.

2. Tidak dilakukannya metode wawancara dalam penelitian, mengingat kesibukan dari pihak responden. Responden meminta agar kuesioner ditinggalkan, sehingga peneliti tidak bisa mengendalikan jawaban responden, kuesioner yang diberikan kepada sumber daya manusia harus memiliki indikator stratanya. Oleh karena itu, jawaban yang diberikan oleh responden belum tentu menggambarkan keadaan sebenarnya.

3. Penelitian ini hanya menggunakan variabel kompetensi sumber daya manusia, tekanan eksternal, komitmen organisasi dan sistem pengendalian intern terhadap penerapan transparansi pelaporan keuangan pemerintah daerah.

\section{Saran}

1. Mengenai kompetensi sumber daya manusia dari hasil penelitian menunjukkan bahwa para aparatur membutuhkan upaya peningkatan SDM melalui pengetahuan, keterampilan dan sikap, hal ini agar aparatur dapat mengerti dan paham dengan apa yang dikerjakan dan tujuan organisasi. sehingga semakin berkompeten sumber daya manusia/aparatur dibidang nya, maka semakin baik pula penerapan transparansi pelaporan keuangan.

2. Mengenai tekanan eksternal disarankan kepada pemerintah untuk dapat menyesuaikan dengan adaya perubahan regulasi, karena tekanan eksternal akan membantu diterapkannya transparansi pelaporan keuangan dipemerintahan

3. Mengenai Komitmen Organisasi disarankan setiap anggota organisasi harus mengimplementasikan tujuan dalam organisasi dengan kesadaran penuh khususnya bagi anggota penatausahaan keuangan, sehingga dapat menciptakan tata kelola pemerintahan yang baik.

4. Mengenai sistem pengendalian intern hasil penelitian menunjukkan bahwa pemerintah melakukan penyelenggarakan kegiatan pengendalian atas keseluruhan kegiatan di instansi masing-masing. hal ini agar semakin baik sistem pengendalian intern dilakukan 
maka semakin baik pula penerapan transparansi pelaporan keuangan dilakukan.

\section{DAFTAR PUSTAKA}

A.A Anwar Prabu Mangkunegara. 2012. Evaluasi Kinerja Sumber Daya Manusia. Bandung: PT. Refika Aditama.

Davici, Nadia. 2016. Pengaruh Tekanan Eksternal, Komitmen Manajemen dan Faktor Politik Terhadap Transparansi Laporan Keuangan (studi empiris di OPD Kab. Agam). JOM Universitas Negeri Padang

DiMaggio, P. J. dan W. W. Powell. 1983. The IronCage Revisited:Institutional Isomorphismand Collective Rationalityin Organizational Fields. American Sociological Review

Falkman, P.dan Tagesson, T. 2008. Accrual Accounting Does Not Necessarily Mean Accrual Accounting: Factors that Counteract Complaince with Accounting Standars in Swedish Municipal Accounting. Scandinavian Journal of Management Vol 24: 271-283

Fardian, Deddi. 2012. Pengaruh Faktor Politik,Ketidakpastian Lingkungan Dan Kompetensi Sumber Daya Manusia Terhadap Penerapan Transparansi Pelaporan Keuangan Pemerintah Kota Padang.Jurnal akuntansiUniversitas NegeriPadang,2012.

Frumkin, P dan J. Galaskiewicz. 2004. Institutional Isomorphism dan Public Sector Organizations. Journal of Public Administration Research and Theory.

Hutapea, Parulian dan Nurianna Thoha. 2008. Kompetensi Komunikasi Plus: Teori, Desain, Kasus dan Penerapan untuk HR dan Oraganisasi yang Dinamis. Penerbit: Gramedia Pustaka Utama. Jakarta

Kristianten. 2006. Transparansi Anggaran Pemerintah. Jakarta: Rineka Cipta.

Latan, Hengki dan Imam Gozali. 2017.Partial Least Squares; Konsep, Metode dan Aplikasi Mengguunakan Program WarpPLS5.0. Edisi Ketiga. Penerbit Universitas Diponegoro. Bandung

Mahmudi. 2007. Analisis Laporan Keuangan. cetakan ke14. Yogyakarta:Liberty

Mardiasmo. 2018. Otonomi dan Manajemen Keuangan Daerah. Andi. Yogyakarta

2004. Otonomi dan

Manajemen

Keuangan Daerah. Andi. Yogyakarta
Marthis, R.L. \& J.H. Jackson. 2006. Human Resource Management: Manajemen Sumber Daya Manusia. Terjemahan Dian Angelia. Jakarta : Salemba Empat

Meyer, J.dan B. Rowan. 1977. Institusional Organizations Formal Structure as Myth and Ceremony. The American Journal of Sociology

M. Arsyadi Ridha, dan Hardo Basuki. 2012. Pengaruh tekanan eksternal, ketidakpastian lingkungan, dan komitmen management terhadap penerapan transparansi pelaporan keuangan. SNAAkuntansi 2012

Peraturan Pemerintah Republik Indonesia Nomor 60 Tahun 2008 tentang Sistem Pengendalian Intern Pemerintah

Peraturan Pemerintah Republik Indonesia Nomor 71 Tahun 2010 tentang Standar Akuntansi Pemerintah

Rai, I Gusti Agung. 2008. Audit Kinerja Pada Sektor Publik: Konsep, Praktik dan Studi Kasus. Jakarta: Salemba Empat.

Ratmono, Dwi.2013. Pelaporan Keuangan Pemerintah Daera Di Internet: Pengujian Teori Institusional Dan Keagenan. (studi empiris pemerintah daerah di indonesia). Volume 1 Nomor 2. Media Ilmiah Akuntansi

Robbins SP, dan Timothy A. Judge. 2015. Perilaku organisasi: konsep kontroversi, Applikasi, Alih Bahasa Hadayana Pujaatmuka dan Benyamin Molan. Edisi kedelapan. JILID II. Penerbit Prenhalindo. Jakarta

Scott, W. R. 1987. The Adolescence of Institutional Theory. Administrative Science Quarterly.

Sholihin, Mahfud, Ph. D dan Ratmono Dwi, Dr.2013. "Analisis SEM-PLS dengan WarpPLS 3.0 untuk hubungan Nonlinier dalam penelitian Sosial dan Bisnis." Penerbit Andi. Yogyakarta

Sugiyono. 2018. Metode Penelitian Kuantitatif, Kualitatif, dan $R \& D$. Alfabeta. Bandung. 2019. Metode Penelitian, Kuantitatif, Kualitatif dan $R \& D$. Penerbit Alfabeta. Bandung

Utamaningsih, Alifiulahtin. 2014. Perilaku Organisasi: Kajian Teoritik dan Empirik Terhadap Budaya Organisasi, Gaya Kepemimpinan, Kepercayaan dan Komitmen. Cetakan 1. UB Press. Malang

Widodo, Joko. 2001. Good Governance, Telaah dari Dimensi Akuntabilitas dan Kontrol Birokrasi pada era Desentralisasi dan Otonomi Daerah. Surbaya:CV Cutra Media 
Volume 8, Nomor 2, Agustus 2020

Yusuf, Ria Mardiana dan Darman Syarif, 2008. Komitmen Organisasi, Nas Media Pustaka; Makassar

Zimmerman, J. 1977. The Municipal Accounting Maze: An Analysis of Political Incentive.

Journal of Accounting Research Vol 15: 107144. 
